\title{
PEMBUATAN MURAL TEMA TANAMAN DAN BINATANG SEBAGAI PENGUATAN PROGRAM ADIWIYATA DAN MEDIA PEMBELAJARAN SENI RUPA ANAK USIA DINI TK DI KALIJAMBE SRAGEN
}

\author{
Endang Widiyastuti ${ }^{1}$, MY Ning Yuliastuti ${ }^{2}$, Esterica Yunianti ${ }^{3}$, Nanang Yulianto ${ }^{4}$ \\ Corresponding email: endangwidiyastuti27@yahoo.com
}

\begin{abstract}
ABSTRAK
Tujuan pengabdian yang akan dilakukan adalah pembuatan mural tema tanaman dan binatang untuk penguatan program sekolah adiwiyata dan media pembelajaran seni rupa anak usia dini di Kecamatan Kalijambe Sragen. Metode yang akan digunakan melalui pelatihan dan dan pendampingan melalui pendekatan partisipatif dan kolaboratif berpijak pada hasil observasi dan wawancara secara mendalam mengenai tema pembelajaran yang ada di TK sebagai pertimbangan utama dalam berkarya mural dengan metode direct practice menggambar langsung lukisan pada dinding TK. Hasil karya lukisan dinding mural dengan tema pembelajaran yang ada di Tk dapat dimanfaatkan untuk meningkatkan kualitas pembelajaran seni rupa anak usia dini. Melalui Pelatihan dan pendampingan pembelajaran seni rupa anak usia dini dalam kegiatan menggambar yang memanfaatkan visualisasi karya dari hasil penerapan seni mural yang telah dilakukan.
\end{abstract}

Kata kunci: mural, program adiwiyata, media pembelajaran

DOI: https://dx.doi.org/10.20961/dedikasi.v2i2.45255

\section{PENDAHULUAN}

Definisi sekolah menurut KBBI adalah "bangunan atau lembaga untuk belajar dan mengajar serta tempat menerima dan memberi pelajaran" atau di wikipedia menerangkan bahwa sekolah merupakan lembaga yang dirancang untuk pengajaran siswa/murid di bawah pengawasan guru. Para ahli mengatakan sekolah adalah sebuah lembaga, dan kata sekolah berasal dari bahasa latin yang artinya waktu luang/senggang. Sehingga dapat dikesimpulkan bahwa sekolah ialah lembaga/tempat anak-anak menghabiskan waktu luangnya untuk bermain dan belajar (http://datasekolah.net/profil/). Secara harfiah sekolah berfungsi untuk mengembangkan daya pikir anak (supaya pintar), melatih kedisiplinan/tatakrama, memiliki mental kuat dan kerja keras, bertanggung jawab, menanamkan jiwa sosial dalam bermasyarakat dan mengembangkan identitas diri anak supaya lebih kreatif (http://datasekolah. net/profil/).

Oleh karena itu sekolah-sekolah di semua jenjang terutama Taman KanakKanak berlomba-lomba dalam menciptakan lingkungan sekolah yang nyaman, menarik untuk menunjang proses pembelajaran. Demikian pula halnya di 
Kecamatan Kalijambe Kabupaten Sragen terdapat beberapa sekolah Taman Kanak-Kanak yang sedang merintis untuk menjadikan sekolahnya memiliki lingkungan yang nyaman dan menarik. Upaya tersebut dihadapkan pada konteks penataan ruang dan lingkungan sekolah yang rapi, bersih. Penciptaan lingkungan sekolah yang bersih, rapi, indah, nyaman, dan menarik ini juga sebagai pendukung program adiwiyata sekolah. Adiwiyata merupakan upaya membangun program atau wadah yang baik dan ideal utnuk mendapatkan ilmu pengetahuan dan berbagai norma serta etika yang dapat menjadi dasar manusia menuju terciptanya kesejahteraan hidup untuk cita-cita pembangunan berkelanjutan. Adiwiyata merupakan nama program pendidikan lingkungan hidup.

Berkaitan dengan penciptaan lingkungan sekolah yang nyaman dan menarik, maka upaya yang dapat dilakukan adalah salah satunya dengan pemanfaatan karya seni mural pada tembok-tembok lingkungan sekolah. Mural adalah cara menggambar atau melukis di atas media dinding, tembok atau permukaan luas yang bersifat permanen lainnya. Mural berasal dari kata 'murus', kata dari Bahasa Latin yang memiliki arti dinding. Dalam pengertian kontemporer, mural adalah lukisan berukuran besar yang dibuat pada dinding (interior ataupun eksterior), langit-langit, atau bidang datar lainnya. Susanto (2002:76) memberikan definisi mural sebagai lukisan besar yang dibuat untuk mendukung ruang arsitektur. Definisi tersebut bila diterjemahkan lebih lanjut, maka mural sebenarnya tidak bisa dilepaskan dari bangunan dalam hal ini dinding. Dinding dipandang tidak hanya sebagai pembatas ruang maupun sekedar unsur yang harus ada dalam bangunan rumah atau gedung, namun dinding juga dipandang sebagai medium untuk memperindah ruangan.

Lukisan berukuran besar pada dinding gedung Taman Kanak-Kanak dengan pemanfaatan seni mural tersebut juga dapat digunakan sebagai sarana media pembelajaran untuk memperkenalkan tema pembelajaran yang ada di Taman Kanak-Kanak. Pengertian tema adalah topik yang menjadi payung untuk mengintegrasikan seluruh konsep dan muatan pembelajaran melalui kegiatan main dalam mencapai kompetensi dan tingkat perkembangan yang diharapkan. Pembelajaran PAUD yang menggunakan tema disebut pembelajaran tematik. Pembelajaran tematik adalah pembelajaran terpadu yang menggunakan tema untuk mengaitkan beberapa muatan pembelajaran dalam mencapai kompetensi dasar (KD) dan tingkat perkembangan yang diharapkan. Tema dapat memfokuskan perhatian anak sehingga memudahkan terwujudnya sikap, pengetahuan dan keterampilan. Sementara itu tema dalam TK berdasarkan kurikulum 2013 terdiri dari, semester 1 adalah diriku, keluargaku, lingkungan dan binatang; semester 2 adalah tanaman, kendaraan, alam semesta, dan negaraku.

Berdasarkan penjabaran tentang pengertian adiwiyata sebagai nama program pendidikan lingkungan hidup di sekolah dengan lukisan berukuran besar pada dinding gedung Taman Kanak-Kanak sebagai sarana media pembelajaran untuk memperkenalkan tema pembelajaran yang ada di Taman Kanak-Kanak. 
Maka pemanfaatan seni mural dapat digunakan sebagai sarana memperindah visual lingkungan sebagai pendukung program adiwiyata dan sebagai media pembelajaran mengenalkan tema pembelajaran yang ada di Taman Kanak-kanak.

Beberapa permasalahan yang dihadapi kedua mitra dapat diidentifikasi sebagai berikut: lokasi sekolah berada di daerah pinggir, program adiwiyata belum tercipta secara maksimal, pengelolaan sekolah yang bersumber pada penerimaan dana dari siswa kurang mencukupi untuk pengelolaan sarana prasarana penunjang pembelajaran. Permasalah yang menjadi prioritas berdasar analisis permasalah tersebut di atas adalah sebagai berikut:

1. Belum terciptanya lingkungan sekolah yang bersih, rapi, indah, nyaman, dan menarik sebagai pendukung program adiwiyata sekolah.

2. Sarana/media pembelajaran mengenalkan tema pembelajaran kurang maksimal.

Secara umum tujuan pengabdian yang dilakukan adalah pembuatan mural tema tanaman dan binatang untuk penguatan program sekolah adiwiyata dan media pembelajaran seni rupa anak usia dini di Kecamatan Kalijambe Sragen. Sehingga solusi terhadap permasalahan mitra dapat dijabarkan pada tabel berikut di bawah ini.

Tabel 1. Solusi terhadap permasalahan mitra

\begin{tabular}{ll}
\hline \multicolumn{1}{c}{ PERMASALAHAN PRIORITAS } & \multicolumn{1}{c}{ SOLUSI } \\
\hline Permasalahan belum terciptanya & Penerapan seni mural dengan \\
lingkungan sekolah yang bersih, rapi, & menggambar tembok sekolah sebagai \\
indah, nyaman, dan menarik sebagai & sarana memperindah visual \\
pendukung program adiwiyata sekolah & lingkungan sekolah \\
& \\
\hline Sarana/media pembelajaran & Pemanfaatan seni mural di tembok \\
mengenalkan tema pembelajaran & sekolah dengan lukisan yang \\
kurang maksimal & menggambarkan tema pembelajaran \\
& yang ada di Taman Kanak-kanak \\
& sebagai media pembelajaran seni \\
& rupa anak usia dini dalam kegiatan \\
& menggambar \\
\hline
\end{tabular}

Metode yang digunakan dalam pelaksanaan pengabdian dengan pendekatan partisipatif dan kolaboratif dalam penerapan seni mural sebagai sarana memperindah visual lingkungan sekolah dalam mendukung program adiwiyata sekolah. Berpijak pada hasil observasi dan diperkuat dengan melakukan wawancara secara mendalam mengenai tema pembelajaran yang ada di TK sebagai pertimbangan utama dalam menerapkan seni mural dengan metode observasi dan direct practice menggambar langsung lukisan pada dinding TK untuk memperindah visual lingkungan sekolah. Karya lukisan dinding hasil penerapan seni mural yang menggambarkan tema pembelajaran yang ada di TK 
bermanfaat sebagai sarana memperindah visual lingkungan sekolah dalam mendukung program adiwiyata sekolah. Dan sebagai media pembelajaran seni rupa anak usia dini dalam kegiatan menggambar untuk meningkatan kualitas pembelajaran melalui pelatihan dan pendampingan.

Metode pemecahan masalah yang digunakan secara khusus adalah sebagai berikut:

Tabel 2. Metode pemecahan masalah

\begin{tabular}{|c|c|c|}
\hline NO & JENIS LUARAN & METODE \\
\hline 1 & $\begin{array}{l}\text { Karya lukisan dinding hasil } \\
\text { penerapan seni mural yang } \\
\text { menggambarkan tema } \\
\text { pembelajaran yang ada di TK } \\
\text { sebagai sarana memperindah } \\
\text { visual lingkungan sekolah dalam } \\
\text { mendukung program adiwiyata } \\
\text { sekolah }\end{array}$ & $\begin{array}{l}\text { Penerapan seni mural melalui } \\
\text { pendekatan partisipatif dengan } \\
\text { metode observasi dan direct practice } \\
\text { menggambar langsung lukisan pada } \\
\text { dinding TK untuk memperindah visual } \\
\text { lingkungan sekolah }\end{array}$ \\
\hline 2 & $\begin{array}{l}\text { Peningkatan kualitas } \\
\text { pembelajaran seni rupa anak } \\
\text { usia dini }\end{array}$ & $\begin{array}{l}\text { Pelatihan dan pendampingan } \\
\text { pembelajaran seni rupa anak usia } \\
\text { dini dalam kegiatan menggambar } \\
\text { yang memanfaatkan visualisasi karya } \\
\text { dari hasil penerapan seni mural yang } \\
\text { telah dilakukan. }\end{array}$ \\
\hline
\end{tabular}

Alur berpikir pemecahan masalah dapat dibuat skema sebagai berikut:

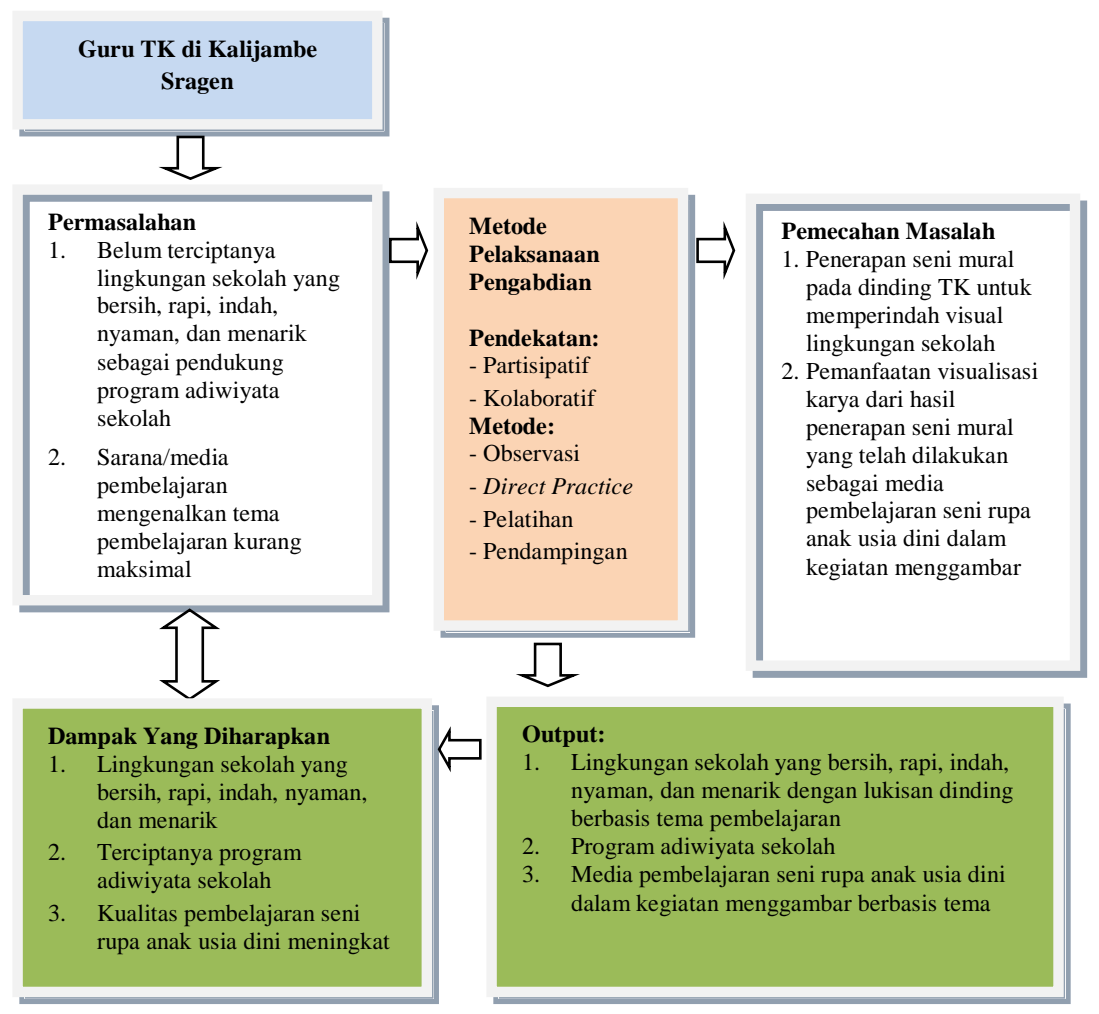


Bagan 1. Alur berpikir pemecahan masalah

Evaluasi pelaksanaan program dan keberlanjutan program setelah selesai kegiatan PKM dilaksanakan.

Tabel 3. Evaluasi program

\begin{tabular}{cll}
\hline No. & \multicolumn{1}{c}{ PROGRAM } & \multicolumn{1}{c}{ EVALUASI } \\
\hline 1 & $\begin{array}{l}\text { Terciptanya lingkungan sekolah } \\
\text { yang bersih, rapi, indah, nyaman, } \\
\text { dan menarik sebagai pendukung } \\
\text { program adiwiyata sekolah }\end{array}$ & $\begin{array}{l}\text { Evaluasi pada visualisasi karya } \\
\text { lukisan dinding hasil dari penerapan } \\
\text { seni mural yang dilakukan }\end{array}$ \\
\hline 2 & Peningkatan kualitas pembelajaran & \\
& seni rupa anak usia dini & Evaluasi pada peningkatan kualitas \\
& & pembelajaran seni rupa anak usia \\
& & dini dalam kegiatan menggambar \\
& & setelah pelatihan berlangsung dan \\
& & terencana secara periodik dari proses \\
& & sampai selesai dengan pemanfaatan \\
& & lukisan dinding hasil dari penerapan \\
& & seni mural yang dilakukan \\
\hline
\end{tabular}

\section{PEMBAHASAN}

\section{Profil TK Dharma Wanita III Kalijambe Sragen}

TK Dharma Wanita III Kalijambe Sragen adalah sekolah Taman Kanakkanak yang beralamatkan di Jalan Raya Solo-Purwodadi km 15 kecamatan Kalijambe kabupaten Sragen. TK Dharma Wanita III Kalijambe Sragen mempunyai 3 kelas yaitu 1 kelas untuk kelompok A dan 2 kelas untuk kelompok B. TK Dharma Wanita III Kalijambe Sragen dipimpin oleh Ibu Sri Mulyati, S.Pd berjenjang pendidikan S1 PAUD yang juga merangkap sebagai guru kelas kelompok A. TK Dharma Wanita III Kalijambe mempunyai 4 guru yang terdiri dari wali kelas maupun guru pendamping dengan kualifikasi 3 berjenjang pendidikan S1, 1 berjenjang pendidikan SLTA. Adapun jumlah anak didik di TK Dharma Wanita III Kalijambe pada tahun 2019/2020 adalah 62 yang terdiri dari 20 anak di kelas A dan 42 anak di kelas B. 


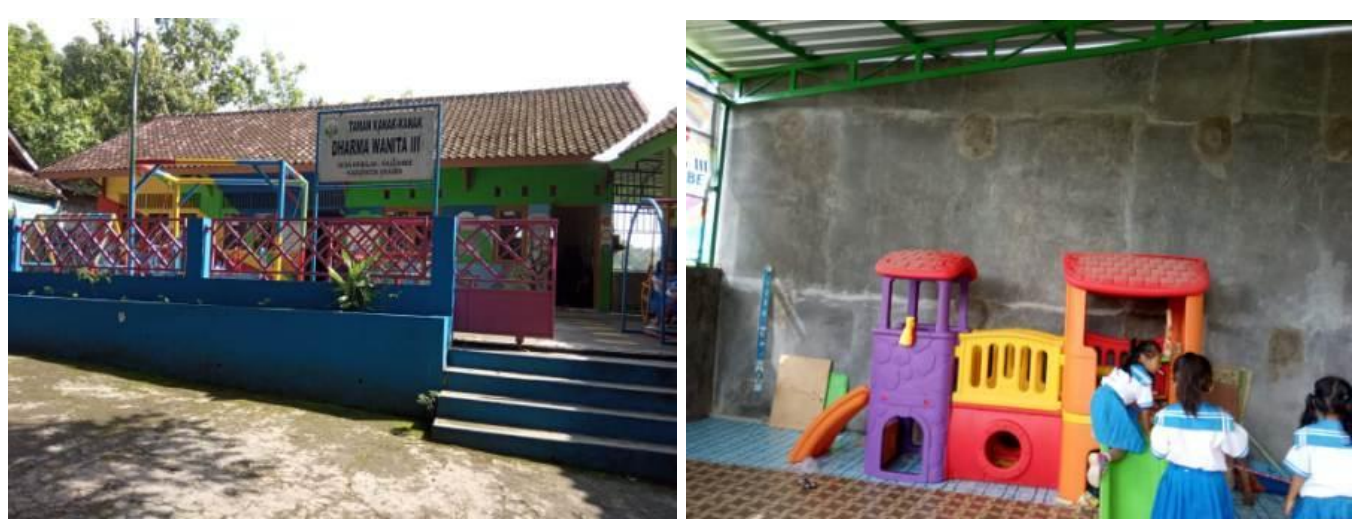

Gambar 1. TK Dharma Wanita III Kalijambe Sragen

Sarana dan Prasarana yang terdapat di TK Dharma Wanita III Kalijambe Sragen adalah pertama, Ruangan Kantor dan Guru yang memiliki kondisi baik dengan luas $\pm 3 \times 6$ meter. Kantor ini digunakan sebagai ruang penanggung jawab sekolah dan Ruang guru yang memiliki kondisi baik. Ruang ini dipergunakan untuk kunjungan-kunjungan wali murid dan tamu-tamu luar yang datang. TK Dharma Wanita III Kalijambe Sragen memiliki 3 ruang kelas dan juga memiliki Sarana Pendukung yaitu Kamar mandi dan WC yang berjumlah satu dalam kondisi cukup baik. Tempat parkir dalam kondisi baik. Dan Halaman bermain dalam kondisi yang baik yang digunakan untuk bermain anak.

\section{Profil TK Pertiwi I Kalimacan Kalijambe Sragen}

TK Pertiwi I Kalimacan adalah sekolah Taman Kanak-kanak di bawah yayasan cabang yang berada di sragen. TK Pertiwi I Kalimacan mempunyai 2 kelas yaitu kelas untuk kelompok A dan kelas untuk kelompok B. TK Pertiwi I Kalimacan beralamatkan di Jalan Raya Solo-Purwodadi km 14. TK Pertiwi I Kalimacan dipimpin oleh Ibu Sri Mulyati,S. Pd berjenjang pendidikan S1 PAUD yang juga merangkap sebagai guru kelas kelompok A. TK Pertiwi I Kalimacan mempunyai 4 guru yang terdiri dari wali kelas maupun guru pendamping dengan kualifikasi 3 berjenjang pendidikan S1, 1 berjenjang pendidikan D2. Untuk karyawan terdiri dari 1 orang penjaga sekolah dan kepolisian sebagai pelindung dan penasehat. Adapun jumlah anak didik di TK Pertiwi I Kalimacan pada tahun 2019/2020 adalah 29 anak. Adapun Visi dan Misi TK Pertiwi I Kalimacan adalah sebagai berikut: a. Visi: Unggul dalam berprestasi santun dalam berbudi. b. Misi: 1. Melaksanakan program pembelajaran dan bimbingan secara efektif sehingga kemampuan anak dapat berkembang secara optimal, sesuai dengan potensi yang dimiliki. 2. Menumbuhkan serta mengembangkan semangat persatuan dan kesatuan dalam kehidupan bersemangat. 

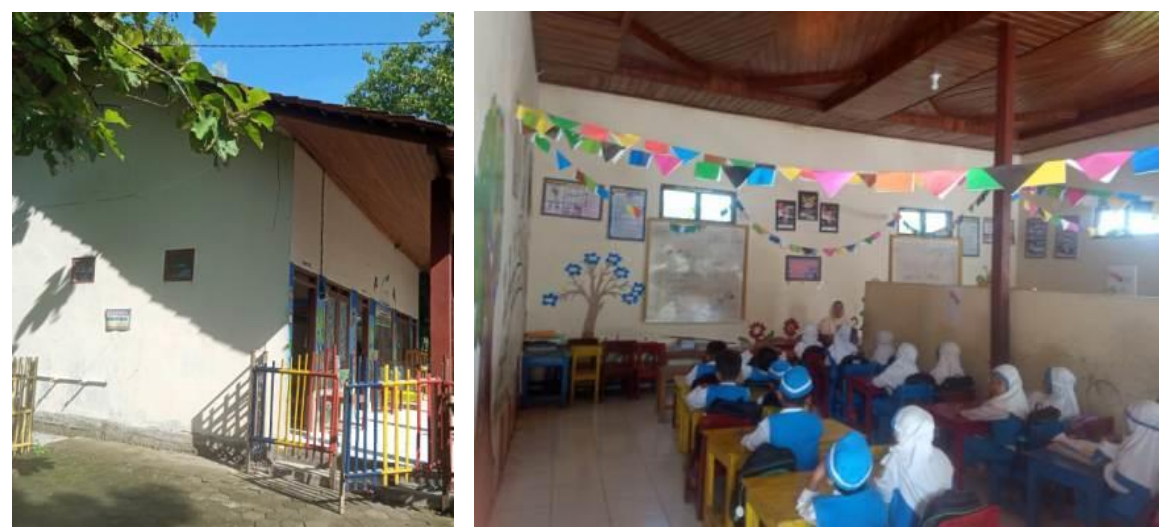

Gambar 2. TK Pertiwi I Kalimacan Kalijambe Sragen

Sarana dan Prasarana yang terdapat di TK Pertiwi I Kalimacan adalah pertama, Ruangan Kantor yang memiliki kondisi baik dengan luas $\pm 3 \times 6$ meter. Kantor ini digunakan sebagai ruang penanggung jawab sekolah. Kedua, Ruang guru yang memiliki kondisi baik. Ruang ini dipergunakan untuk kunjungan kunjungan wali murid dan tamu-tamu luar yang datang. TK Pertiwi I Kalimacan juga memiliki Sarana Pendukung yaitu Kamar mandi dan WC yang berjumlah satu dalam kondisi cukup baik. Tempat parker dalam kondisi baik. Dan Halaman bermain luar dalam kondisi yang baik yang digunakan untuk bermain anak.

\section{HASIL YANG DICAPAI}

Kegiatan Pengabdian pada Masyarakat ini telah dilaksanakan sesuai dengan rencana di proposal pengabdian. Secara terperinci kegiatan dan hasil yang telah dicapai dapat diuraikan sebagai berikut.

1. Koordinasi Tim Pengabdi dan Koordinasi Tim Pengabdi dengan Mitra

Kegiatan awal yang telah dilakukan untuk mencapai program dilakukan dengan mengadakan koordinasi, baik dengan sesama anggota Tim Pengabdi maupun dengan pihak Mitra yaitu sekolah.

a. Koordinasi Tim Pengabdi

Koordinasi Tim Pengabdi dilakukan untuk menyatukan persepsi tentang berbagai program dan langkah-langkah yang akan dilakukan. Beberapa hal yang akan dilakukan dapat diuraikan sebagi berikut: 1). Bentuk kegiatan; 2) Alat dan bahan yang akan digunakan; 3). Luaran kegiatan yang akan dicapai pada setiap tahap; dan 4). Target luaran kegiatan pengabdian secara keseluruhan. Selanjutnya, setelah koordinasi Tim Pengabdi dilakukan, langkah berikutnya melakukan koordinasi dengan Mitra.

b. Koordinasi Tim Pengabdi dengan Mitra

Pada kegiatan koordinasi tim pengabdi dengan mitra ini, Tim Pengabdi mendatangi kedua mitra dengan menyampaikan beberapa hal terkait program yang akan dilakukan di lapangan. Adapun Pihak mitra yang diajak berkoordinasi adalah Kepala Sekolah. Beberapa hal yang 
dibahas dalam koordinasi ini antara lain: 1). Bentuk kegiatan; 2) Alat dan bahan yang akan digunakan; 3) Jadwal kegiatan yang akan dilakukan; 4). Peserta yang akan dilibatkan dalam kegiatan; 5). Luaran kegiatan yang akan dicapai; dan 6). Target luaran kegiatan pengabdian secara keseluruhan.

2. Pelaksanaan Kegiatan Mural

a. Kegiatan Mural di TK Pertiwi I Kalimacan Kalijambe Sragen

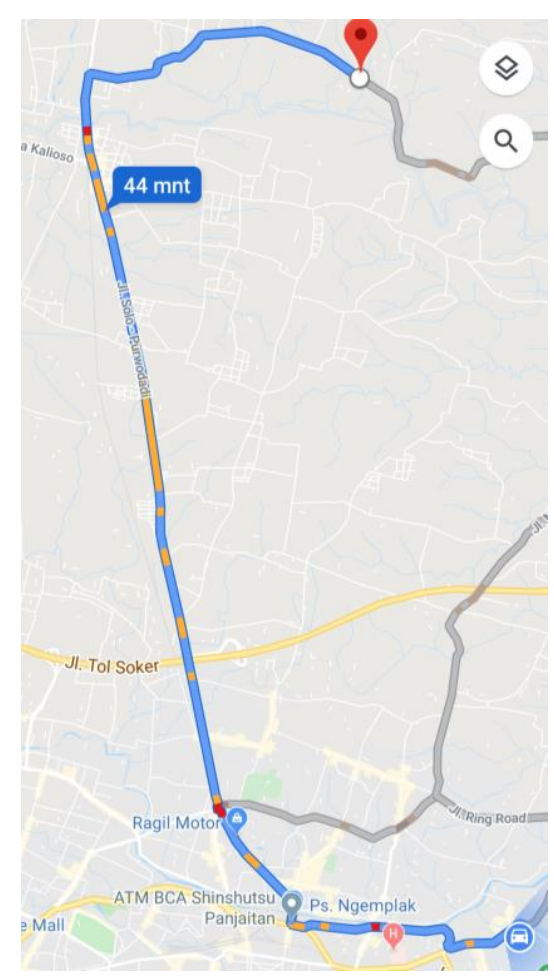

Gambar 3. Peta Lokasi Mitra 1 TK Pertiwi 1 Kalimacan Kalijambe Sragen

Kegiatan mural dilakukan pada Rabu, 17 Juni 2020, diawali dengan koordinasi antara Tim Pengabdi dengan Kepala Sekolah. Selanjutnya mendiskusikan kegiatan dan koordinasi pelaksanaan proses mural yang akan dilakukan. 


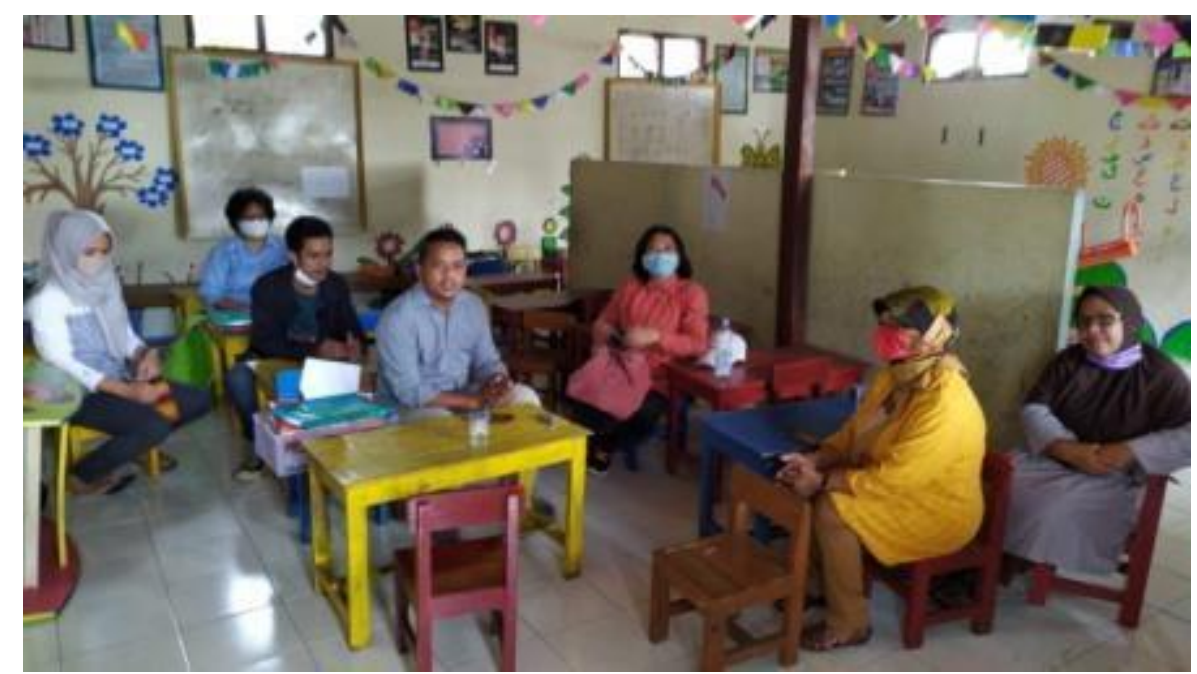

Gambar 4. Tim Pengabdi diterima Kepala Sekolah

Kegiatan mural dimulai jam 08.00 WIB diawali dengan koordinasi tim pengabdi, mencermati bidang yang akan di mural pada lokasi mitra 1. Kemudian pembagian tim dan pembagian bahan untuk mural pada lokasi mitra 2. Selanjutnya Tim Pengabdi untuk lokasi 1 melakukan proses kerja mural.

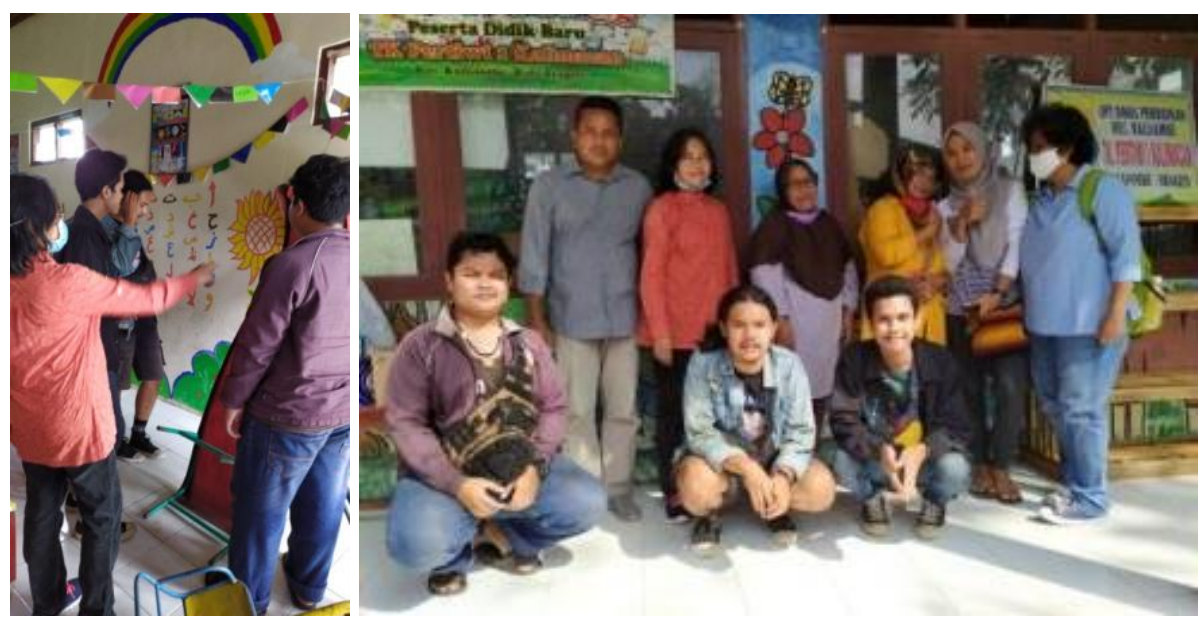

Gambar 5. Koordinasi Tim Pengabdi

Setelah koordinasi tim pengabdi terkait kondisi lokasi mural selesai kemudian dilanjutkan dengan proses pengerjaan mural pada tembok sekolah. Kegiatan proses pengerjaan menggambar mural ini dilaksanakan selama dua hari, dimana hari pertama penyelesaian sketsa dan pewarnaan bagan pada dinding TK. Dan hari kedua adalah kelanjutan pewarnaan hingga finishing mural dengan penorehan outline pada bagan. 

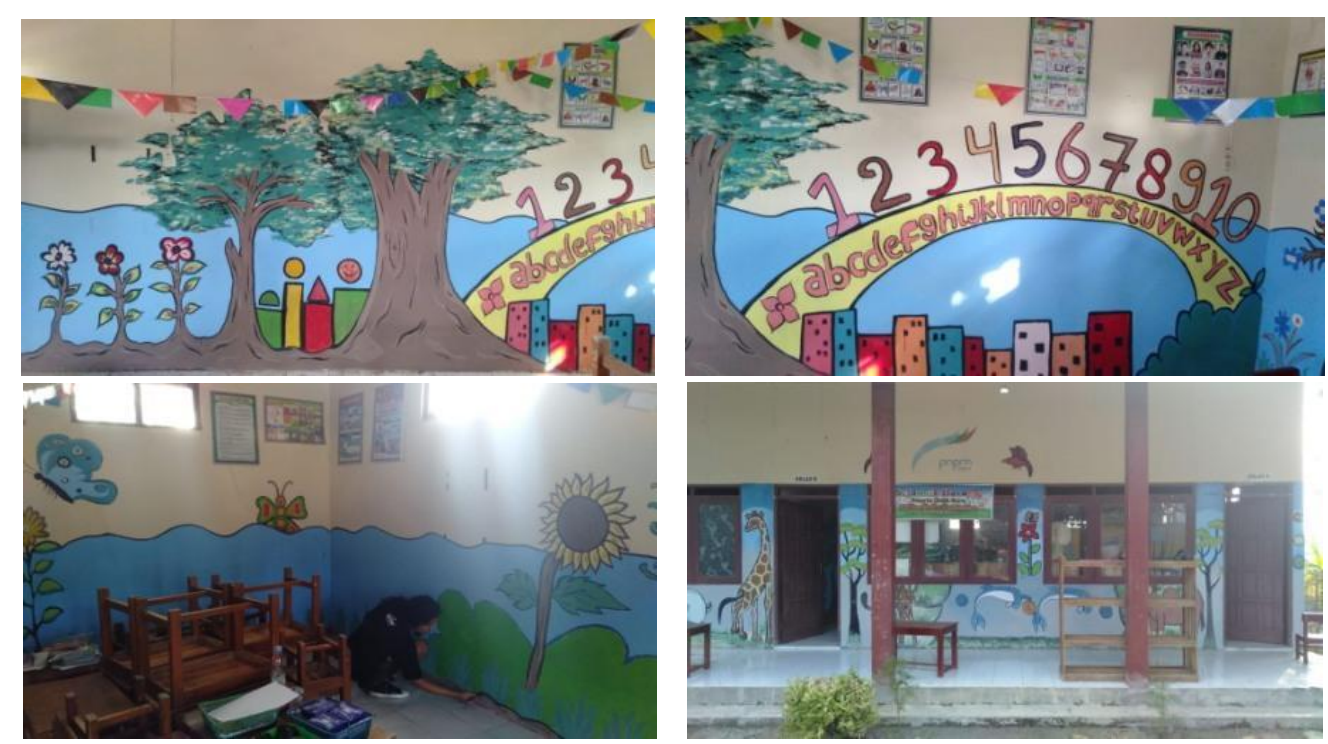

Gambar 6. Hasil Kegiatan Mural di TK Pertiwi I Kalimacan Kalijambe Sragen

b. Kegiatan Mural di TK Dharma Wanita III Kalijambe Sragen

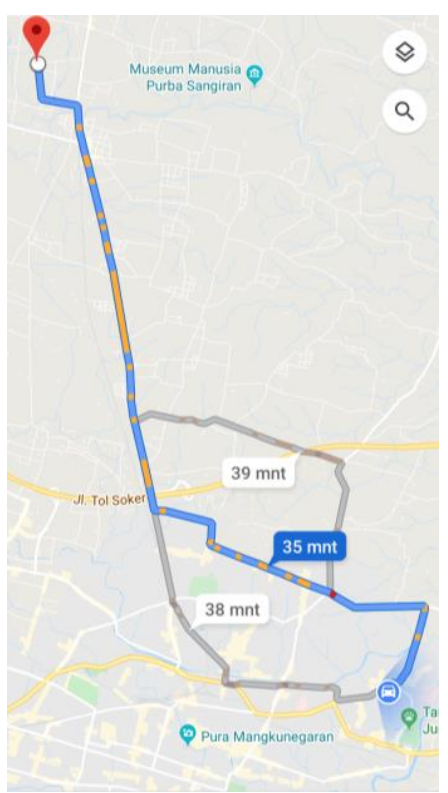

Gambar 7. Peta Lokasi Mitra 2 TK Dharma Wanita III Krikilan Kalijambe Sragen

Kegiatan mural dilakukan pada hari Rabu tanggal 17 Juni 2020, diawali dengan koordinasi antara Tim Pengabdi dengan Kepala Sekolah. Selanjutnya mendiskusikan kegiatan dan koordinasi pelaksanaan proses mural yang akan dilakukan. Kegiatan mural dimulai jam 09.00 WIB diawali dengan koordinasi tim pengabdi, mencermati bidang yang akan di mural pada lokasi mitra 1I. Kemudian tim melakukan persiapan bidang sebagai lokasi penerapan gambar mural. Persiapan ini diawali dengan memberikan dasar pada tembok tempat mural dengan melakukan pengecatan dasar warna putih pada seluruh bidang tembok yang akan di mural. 


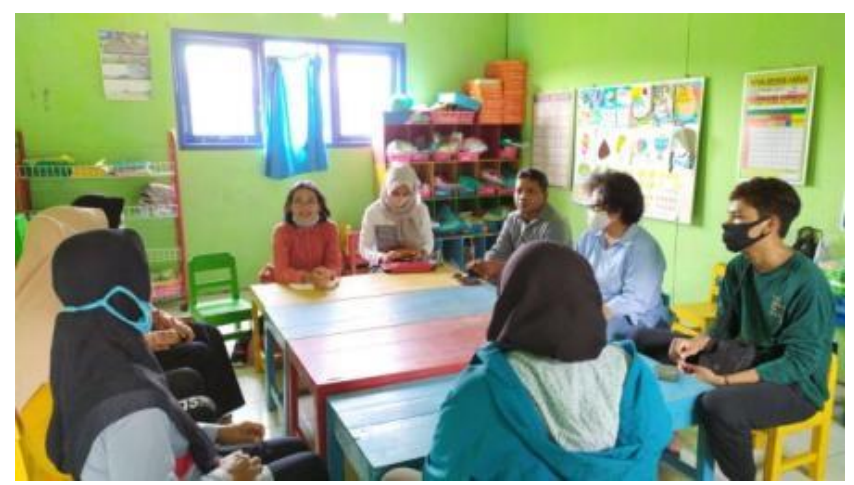

Gambar 8. Koordinasi Tim Pengabdi Dengan Pihak Mitra
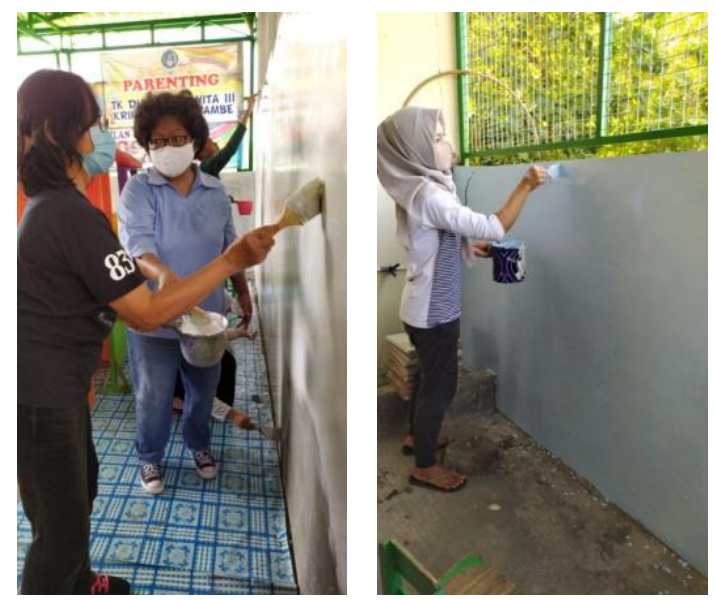

Gambar 9. Pemberian dasar warna putih pada bidang tembok yang akan di mural

Setelah pemberian dasar warna putih pada bidang tembok selesai, dan cat sudah kering. Kemudian dilanjutkan dengan proses pengerjaan mural pada tembok tersebut. Pertama-tama dibuat sket bagan yang akan dibuat, bagan ini bisa berupa binatang dan tumbuhan sesuai tema yang dirujuk dalam kegiatan mural ini. Kemudian proses mural selanjutnya adalah pemberian warna bagan yang telah di sket pada tembok tersebut. Adapun kegiatan proses pengerjaan menggambar mural ini dilaksanakan selama dua hari, dimana hari pertama penyelesaian sketsa dan pewarnaan bagan pada dinding TK. Dan hari kedua adalah kelanjutan pewarnaan hingga finishing mural dengan penorehan outline pada bagan.
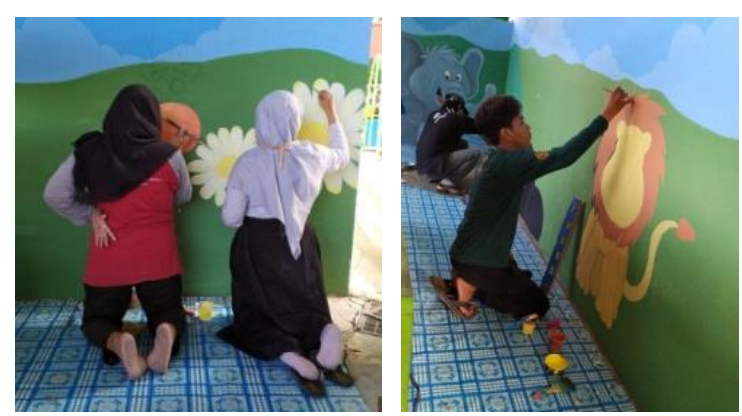


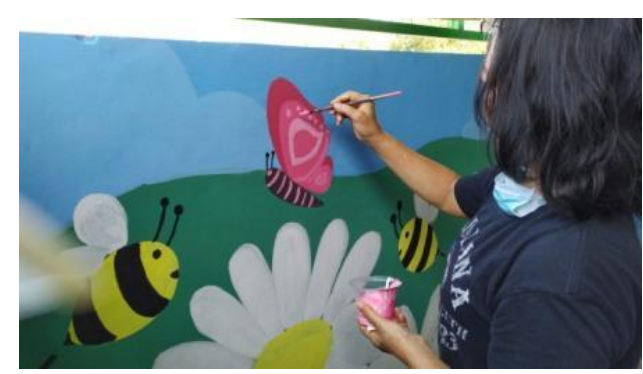

Gambar 10. Pewarnaan bagan dari sket yang telah dibuat

\section{KESIMPULAN}

Karya lukisan dinding hasil penerapan seni mural yang menggambarkan tema pembelajaran yang ada di TK dapat dimanfaatkan sebagai sarana memperindah visual lingkungan sekolah dalam mendukung program adiwiyata sekolah. Adapun metode yang bisa digunakan dalam penerapan seni mural dapat melalui pendekatan partisipatif dengan metode observasi dan direct practice menggambar langsung lukisan pada dinding TK untuk memperindah visual lingkungan sekolah.

Hasil karya lukisan dinding mural dengan tema pembelajaran yang ada di Tk dapat dimanfaatkan untuk meningkatkan kualitas pembelajaran seni rupa anak usia dini. Melalui Pelatihan dan pendampingan pembelajaran seni rupa anak usia dini dalam kegiatan menggambar yang memanfaatkan visualisasi karya dari hasil penerapan seni mural yang telah dilakukan.

\section{DAFTAR PUSTAKA}

Mahmoud Darwish. 2017. Mural. Diakses dari https://www.kobo.com/gb/en/ebook/mural-2

Datasekolah.net. 2017. Apa Pengertian dan Manfaat Sekolah Menurut Para Ahli. diakses dari http://datasekolah.net/profil/

Okego Komunitas. 2016. Pengertian Mural. diakses dari http://okegoartbali.blogspot.com/2016/04/pengertian-mural.html

Unknown. 2013. Mural Definisi dan Perkembangannya. diakses dari http://dinsnusantara.blogspot.com/2013/10/mural-definisi-danperkembangannya.html

PAUD Jateng. 2015. Pengertian Tema PAUD dan Mengapa Menggunakan Tema $P A U D$. diakses dari https://www.paud.id/pengertian-tema-alasanmenggunakan-tema-paud/ 